\title{
Managing succession in conifer plantations: converting young red pine (Pinus resinosa Ait.) plantations to native forest types by thinning and underplanting
}

\author{
by William C. Parker ${ }^{1}$, Ken A. Elliott ${ }^{2}$, Daniel C. Dey ${ }^{1,3}$, Eric Boysen ${ }^{4}$ \\ and Steven G. Newmaster ${ }^{1,5}$
}

\begin{abstract}
The effects of thinning on growth and survival of white pine (Pinus strobus L.), white ash (Fraxinus americana L.), and red oak (Quercus rubra L.), and understory plant diversity were examined in a young red pine (Pinus resinosa Ait.) plantation. Five years after thinning, seedling diameter, height, and stem volume were positively correlated with thinning intensity and the size of canopy openings. Percent survival did not differ among thinning treatments, but was significantly higher in white ash and white pine than red oak. Understory vegetation included 113 species, with species richness increasing with thinning intensity and proximity to neighbouring plant communities. Thinning to create relatively large canopy openings in combination with underplanting can promote the natural succession of young pine plantations to native forest species.
\end{abstract}

Keywords: direct seeding, plant diversity, natural regeneration, red oak, restoration, white ash, white pine

Les effets de l'éclaircie sur la croissance et la survie du pin blanc (Pinus strobus L.), du frêne d'Amérique (Fraxinus americana L.) et du chêne rouge (Quercus rubra L.) et sur la diversité des plantes en sous-étage ont été étudiés dans une jeune plantation de pin rouge (Pinus resinosa Ait.). Cinq années après l'éclaircie, le diamètre, la hauteur et le volume de la tige des semis ont été corrélés positivement avec l'intensité de l'éclaircie et la taille des ouvertures dans le couvert des cimes. Le pourcentage de survie n'a pas différé selon les traitements d'éclaircie, mais il était significativement plus élevé pour le frêne d'Amérique et le pin blanc que pour le chêne rouge. La végétation en sous-étage comprenait 113 espèces, et la diversité des espèces augmentait selon l'intensité d'éclaircie et la proximité de communautés de plantes avoisinantes. Une éclaircie réalisée dans le but de créer d'importantes ouvertures dans le couvert en association avec un regarnissage peut promouvoir la succession naturelle des plantations de jeunes pins vers des espèces forestières indigènes.

Mots-clés: ensemencement direct, diversité des plantes, régénération naturelle, chêne rouge, réhabilitation, frêne d'Amérique, pin blanc

\section{Introduction}

Prior to European settlement, most of south-central Ontario was dominated by forest vegetation. The mesic sites were occupied by the tolerant hardwood species of the Great Lakes - St. Lawrence Forest Region (Rowe 1972), dominated by sugar maple (Acer saccharum Marsh), red maple (Acer rubrum L.), basswood (Tilia americana L.), American beech (Fagus grandifolia Ehrh.), yellow birch (Betula alleghaniensis Britt.), and eastern hemlock (Tsuga canadensis (L.) Carr.) (Delcourt and Delcourt 2000). On the drier sites of this region, eastern white pine (Pinus strobus L.) and red oak (Quercus rubra L.) increased in frequency, with areas of coarse-textured soils supporting white, red (Pinus resinosa Ait.) and jack ( $P$. banksiana L.) pine forests (Whitney 1986, Delcourt and Delcourt 2000). Settlement of southern Ontario in the early to mid1800 s initiated the widespread logging of pine and clearing of

${ }^{1}$ Ontario Ministry of Natural Resources, Ontario Forest Research Institute, 1235 Queen St. E., Sault Ste. Marie, ON P6A 2E5. Email: bill.parker@mnr.gov.on.ca

${ }^{2}$ Ontario Ministry of Natural Resources, South Central Science Section, 659 Exeter Rd, London, ON N6E 1L3.

${ }^{3}$ Current Address: U.S. For. Serv. North Central Research Station, 202 Anhueser-Busch Natural Resources Building, University of Missouri, Columbia, MO 65211, USA.

${ }^{4}$ Ontario Ministry of Natural Resources, Forest Management Branch, 5 th floor, North tower, 300 Water St., Peterborough, ON K9J 8M5.

${ }^{5}$ Current Address: Algoma University College, 1520 Queen St. E., Sault Ste. Marie, ON P6A 2 G4. forests for agriculture (Borczon 1986). By the late 1800s, much of the native forests of this region were eliminated or modified by the new European land use practices.

A large proportion of the forest land brought into cultivation was unsuitable for growing agricultural crops, particularly the coarse-textured soils of the original pine forests. Removal of the protective forest cover and the prevailing agricultural practices often resulted in massive soil erosion, and increased frequency and severity of spring flooding and summer drought. These poor farmlands were ultimately abandoned to further erosion by wind and water, leading to the development of vast areas of desert-like wasteland. Commonly, wind action lifted the light sands forming large "blow pits," depositing the sands in banks downwind. In severe cases, the pits and banks of blow sand areas covered 30 ha or more (Borczon 1986).

At the turn of the century, recognition of the extent and impact of this problem resulted in a series of legislative efforts to encourage reforestation of these degraded forest lands to both control erosion and protect watersheds (Borczon 1986). Red pine was often favoured for planting because of its ability to grow on the infertile, sandy soils. Today, these plantations are an important component of southern Ontario's woodlands. They provide a variety of ecological and social benefits to this mainly urban environment, where little of the original forest remains and forests have been fragmented by development.

The structure and composition of these plantations differ with stand age and history of natural disturbance and management. In older pine plantations, thinning and natural disturbances 
that opened the canopy encouraged the development of an understory of native hardwood and conifer species. Younger plantations with no overstory disturbance history are largely devoid of understory vegetation, and are viewed by some as "biological deserts" (Mosquin et al. 1995).

There is currently great interest in managing the succession of conifer plantations to accelerate their conversion to more natural forest types. The suite of silvicultural treatments needed largely depends on the presence and abundance of advance regeneration of the desired species. In 1993, the Ontario Ministry of Natural Resources in cooperation with the Regional Municipality of Durham developed a research project to identify methods for managing the natural succession of older, previously disturbed, and younger, undisturbed, conifer plantations. In this report, we present the results of a study of the influence of five thinning treatments on: (1) growth and survival of underplanted white pine, red oak, and white ash, and (2) abundance and diversity of naturally regenerated, understory vegetation in a young, 32-year-old red pine plantation.

\section{Materials and Methods \\ Study Site}

This study was established in the Norton Tract of the Durham Regional Forest $\left(43^{\circ} 55^{\prime} \mathrm{N}, 79^{\circ} 10^{\prime} \mathrm{W}\right)$. The site is flat to gently rolling and is located on the Oak Ridges Moraine along the divide between the Lake Simcoe and Lake Ontario watersheds. The study area is a 3.2-ha red pine plantation located within a larger 20.3-ha block of pine (white, red, jack, and Scots pine (Pinus sylvestris $\mathrm{L}$.)) plantations. The study plantation was established in 1962 , with red pine planted at $1.8-\mathrm{m} \times 1.8-\mathrm{m}$ spacing. Thereafter, the plantation received no further treatment. In 1993, the overstory was pure red pine with average stand basal area, height, and diameter (at $1.3 \mathrm{~m}$ ) of $54.7 \mathrm{~m}^{2} \mathrm{ha}^{-1}, 14 \mathrm{~m}$, and $17 \mathrm{~cm}$, respectively. Very little understory vegetation existed and the forest floor consisted largely of a 5-10 cm litter layer of pine needles. Soils are of the Pontypool Sands soil series, with loamy fine sand soils that have a moderately fresh moisture regime with rapid drainage. The A horizon (upper $25 \mathrm{~cm}$ ) is a plow layer (Ap), overlying a 50-cm Bm horizon. Carbonates are present beyond $70 \mathrm{~cm}$.

\section{Experimental Design and Overstory Treatment Description}

The main study area $(120 \mathrm{~m} \times 160 \mathrm{~m} ; 79$ planted (north-south) rows) was divided into 20,30-m $\times 32$-m plots (Fig. 1). Each of these plots was further subdivided in half along an east-west line. Following thinning treatments, the southern half of each plot $(15 \mathrm{~m} \times 32 \mathrm{~m})$ was planted with single, east-west rows of white pine, red oak, and white ash. The northern subplot was left untreated to monitor the ingress of woody and herbaceous vegetation.

Red pine plantations in the Lake States and Ontario have most commonly been by thinned by row and individual tree selection (Horton and Bedell 1960, Lundgren 1981). In this study, we used row thinning, selection thinning, and creation of small canopy gaps to obtain a range in the intensity and spatial distribution of canopy disturbance. Plots in the main study area were randomly assigned one of five treatments, including an uncut control $(\mathrm{CN})$, with each treatment replicated four times. Single (1R) row thinning removed the first of every four rows and decreased basal area by $25 \%$ (residual basal area $\sim 41 \mathrm{~m}^{2}$ $\left.\mathrm{ha}^{-1}\right)$. Double (2R) row thinning removed the first two of every five rows and reduced basal area by about $40 \%\left(\sim 33 \mathrm{~m}^{2}\right.$ $\mathrm{ha}^{-1}$ ). All row thinning was applied in a north-south direction. A selection (SLT) treatment reduced basal area by about $44 \%$ $\left(\sim 31 \mathrm{~m}^{2} \mathrm{ha}^{-1}\right)$, by combining single row thinning with removal of $25 \%$ of the trees in the three adjacent rows. The final treatment (G1) was designed to better simulate natural canopy disturbances. Small, circular canopy gaps, $7 \mathrm{~m}$ in diameter or approximately half the average height of the overstory trees (Hibbs 1982a), were created in plots that also received the SLT treatment. This treatment reduced basal area by about $46 \%$ $\left(\sim 30 \mathrm{~m}^{2} \mathrm{ha}^{-1}\right)$.

A second smaller area ( $0.4 \mathrm{ha})$ about $40 \mathrm{~m}$ to the west of the main block was later added to the study to more closely examine the effect of planting location on seedling growth (Fig. 1). This area was divided into four, $30-\mathrm{m} \times 32$-m plots. These plots were thinned using the G1 method, but seedlings were planted only within the circular understory opening, hereafter referred to as the $\mathrm{G} 2$ treatment.

All thinning was completed in August 1994 using a fellerprocessor and a wheeled forwarder. The feller-processor consisted of a small, tracked excavator fitted with a cutter head and delimber on a jointed boom. The operator harvested and processed logs along a travel corridor created by the row thinning. The length of the cutter arm allowed the extraction of trees up to $4 \mathrm{~m}$ (i.e., 2 rows) away from the cleared rows. Trees were cut, delimbed, cut to 2.4-m lengths, and stacked in small piles $(<10 \operatorname{logs})$ along the edge of the removed rows. Cut logs were loaded on the back of the forwarder and removed from the study plots using the same travel corridors as the feller-processor. Logging damage to residual trees was negligible. Disturbance of the forest floor was largely confined to the path shared by the two machines.

The study area is surrounded by a number of potential sources of propagules for understory colonization and natural regeneration (Fig. 1). These areas include white, Scots, red, and jack pine plantations differing in age and understory development. Mature trees in a fence row, and an old field with scattered Scots pine and several hardwood tree species occur along the southern boundary of the plantation. A residential area and small, open woodland occur to the north of these pine plantations. Tolerant hardwood stands $700 \mathrm{~m}$ to the west and $1 \mathrm{~km}$ to the southeast of the plantation may provide a more distant source of seed.

\section{Artificial Regeneration}

In April 1995, all 24 plots were planted with $2+0$ bareroot white ash, white pine, and red oak seedlings, and direct seeded with red oak acorns. These species are common to the original forests of the region, adapted to the site, and intermediate in shade tolerance. Seedlings were obtained from St. Williams Nursery (St. Williams, ON). Red oak acorns obtained from a 1994 bulk collection from a local seed source were cleaned of damaged seed, and stratified for 46 days at $2^{\circ} \mathrm{C}$. Viability tests indicated germinability of about $90 \%$. Four east-west planting rows were established in the southern half of the 20 plots in the main study area, with $3-\mathrm{m}$ spacing between rows. A single species was planted in each row, with 1.2 -m spacing between planting spots. From north to south, the first three rows were always planted with white pine, red oak, and white ash. The fourth row was seeded with red oak acorns at the same $1.2-\mathrm{m}$ spacing, with five acorns planted to a depth of $2-3 \mathrm{~cm}$ in a $10-\mathrm{cm}$ 


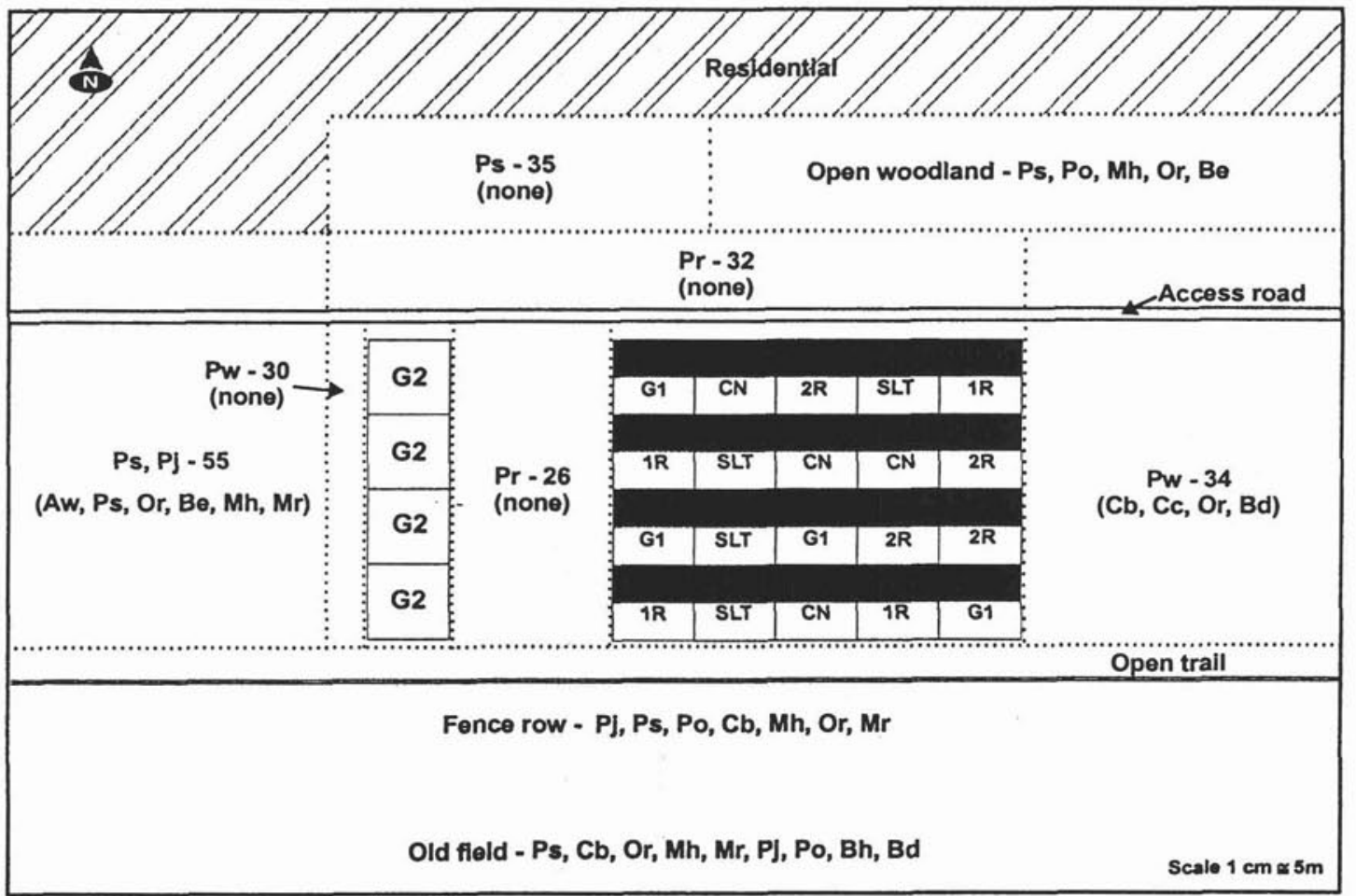

Fig. 1. Thinning treatment location and description of vegetation neighbouring the 32-year-old red pine study plantation. Shading in individual plots refers to the unplanted area. Adjacent pine plantations are identified by species (red (Pr), white (Pw), jack (Pj), and Scots (Ps)) and age. Plantation understory composition of major woody species is noted in parentheses. Species are listed in order of abundance. Open woodland, old field, fence row, and understory tree species codes: white ash (Aw), basswood (Bd), American beech (Be), beaked hazel, (Corylus cornuta Marsh) (Bh), black cherry (Prunus serotina Ehrh.) (Cb), choke cherry (Prunus virginiana L.) (Cc), red oak (Or), sugar maple (Mh), red maple (Ms), Populus sp. (Po).

$\times 15$-cm planting spot. The four $\mathrm{G} 2$ plots were planted only within the circular canopy openings. Five seedlings per species and five groups of four acorns were randomly planted within this opening.

Height and diameter ( $2 \mathrm{~cm}$ above ground) of underplanted seedlings were measured shortly after planting to provide baseline data for future growth comparisons. Height, diameter, and survival of underplanted seedlings were measured at the end of each growing season from 1995-1999. The number of oak seedlings, the height and diameter of the largest seedling, and survival were determined for each acorn planting spot.

The relative increase in seedling stem size since time of planting was estimated by the ratio of incremental change in height, diameter, or volume since the first measurement date to the total measured in 1999 (year 5). Relative height growth rate was integrated over the entire five-year, post-treatment period. Relative diameter and volume growth were integrated over a four-year period since diameter was not measured on seeded red oak until the second year after planting.

\section{Understory vegetation and plant diversity}

A comprehensive botanical survey of all understory plant species was conducted in August 1999, five years after thinning. Four, $10-\mathrm{m} \times 10$-m plots were located in each of the 24 treatment plots (two in the north (unplanted), two in the south (planted) subplot). Percent cover (i.e., abundance) was estimated for each species relative to the $100-\mathrm{m}^{2}$ plot. Frequency of occur- rence by species was estimated as the proportion of the 16,100 $\mathrm{m}^{2}$ plots per treatment that had at least one individual present. Each plant species identified in the 96 plots was assigned a layer code: (1) dominant tree $(>10 \mathrm{~m})$, (2) subdominant tree $(<10 \mathrm{~m})$, (3) woody vegetation (trees, shrubs, vines), $2.0-10.0 \mathrm{~m}$, $0.5-2.0 \mathrm{~m}$, or $<0.5 \mathrm{~m}$ in height, (4) herbs, grasses, and sedges, and (5) cryptogams (pteridophytes, bryophytes, lichens). The species rarity ranking, species nomenclature, and exotic status follow the Ontario Plant List (Newmaster et al. 1998). For comparative purposes, understory vegetation was also surveyed in four locations within a nearby 70 -year-old conifer plantation. Alternate rows of white and red pine were planted in 1929, and the plantation thinned at 32,42 , and 55 years. In 1993, the plantation had an average basal area of $31 \mathrm{~m}^{2} \mathrm{ha}^{-1}$ and height of $28 \mathrm{~m}$, with abundant advance reproduction of woody species.

Species richness (Fisher et al. 1942, McIntosh 1967, Peet 1974) was used as a measure of plant diversity. Mean species richness (i.e., the mean number of species present) was calculated for each thinning treatment, plots grouped by the number $(0,1,2-3)$ of plot borders, "edges," adjacent to plant communities neighbouring the study area, and for functional plant groups: woody, herbaceous (herbs, grasses, sedges), and cryptogams.

\section{Overstory characteristics}

In fall 1996, a LAI-2000 plant canopy analyzer (LiCor, Inc., Lincoln, NE, USA) was used to estimate leaf area index (LAI) 
Table 1. Thinning intensity, estimated size and number of canopy openings, and plot-averaged values for mean ( $\pm 1 \mathrm{SE})$ leaf area index (LAI), percent crown closure, and percent PPFD in the understory for six thinning treatments ${ }^{1}$

\begin{tabular}{lccccc}
\hline Treatment & $\begin{array}{c}\text { Thinning } \\
\text { intensity }(\%)\end{array}$ & $\begin{array}{c}\text { Average number and } \\
\text { opening area }\left(\mathbf{m}^{2}\right)\end{array}$ & LAI & $\begin{array}{c}\text { Crown } \\
\text { closure }(\%)\end{array}$ & $\begin{array}{c}\text { Daily PPFD } \\
(\% \text { full sunlight })\end{array}$ \\
\hline Control (CN) & 0 & 0 & $3.14(0.09)$ & $93.2(0.5)$ & $6.7(0.2)$ \\
1 row (1R) & 25 & 5,108 & $2.31(0.19)$ & $85.4(2.2)$ & $13.3(0.6)$ \\
2 row (2R) & 40 & 4,162 & $1.67(0.27)$ & $75.2(5.2)$ & $17.7(0.9)$ \\
Selection (SLT) & 44 & 5,108 & $2.07(0.15)$ & $81.8(1.6)$ & $16.1(0.7)$ \\
Gap (G1) & 46 & $48,2.5$ & $1.69(0.14)$ & $75.5(3.2)$ & $33.5(1.9)$ \\
Gap (G2) & 46 & $1,38.5$ & $1.71(0.25)$ & $71.3(5.7)$ & \\
\hline
\end{tabular}

${ }^{1}$ Estimates of average canopy opening size and number assume $2-\mathrm{m} \times 2-\mathrm{m}$ spacing, fully stocked conditions, and roughly circular crowns of overstory red pine that did not overlap at time of thinning. Canopy openings for 1R and 2R thinnings are rectangular, G1 and G2 are circular, and those for SLT are a combination of both.

and percent crown closure of each treatment plot. Eleven instantaneous measurements at $1 \mathrm{~m}$ above the ground, collected along a systematic transect through each of the 24 plots, were used to estimate plot-averaged treatment values. All measurements were made on a completely overcast day. A LI-190s quantum sensor attached to the canopy analyzer was used to measure photosynthetic photon flux density (PPFD: light intensity between $400-700 \mathrm{~nm}$ ). Periodic above canopy PPFD measurements were made in an adjacent opening. Mean daily percent PPFD in the understory was estimated as the ratio of below to above canopy PPFD (Messier and Puttonen 1995). All PPFD measurements in the main treatment area were collected at the same time and position as canopy measurements $(n=11)$. In the $\mathrm{G} 2$ plots, PPFD was measured only within the canopy gap $(n=11)$.

\section{Statistical analysis}

The GLM procedure of SAS (SAS Institute Inc. 1989) was used for analysis of variance (ANOVA) of treatment effects on growth and survival of artificial regeneration within the main study area. The following mixed general linear model was used,

$$
\mathrm{u}_{\mathrm{ijk}}=\mathrm{T}_{\mathrm{i}}+\mathrm{P}_{(\mathrm{i}) \mathrm{j}}+\mathrm{S}_{\mathrm{k}}+\mathrm{TS}_{\mathrm{ik}}+\mathrm{PS}_{(\mathrm{i}) \mathrm{jk}}+\mathrm{E}_{(\mathrm{ijk}) \mathrm{l}}
$$

with thinning (T) and species/seedling type (S) as fixed factors, and plot $(\mathrm{P})$ identified as a random factor. A Tukey-Kramer test was used for mean comparisons. Variance in percent survival data was stabilized using an arcsine square root transformation. Because the G2 plots were established outside the main study area, and were underplanted with fewer seedlings per species, this treatment was not included in the ANOVA. Instead, treatment means and standard errors (SE) were used for comparison of G2 with the other thinning treatments. Non-parametric statistics and a Kruskal-Wallis test were used for analysis of understory species richness because of non-homogeneity of variance (Lavene statistic, $p \leq 0.05$ ). The relationship between thinning intensity (i.e., percent basal area reduction) and mean LAI, percent crown closure, and understory PPFD was examined using Pearson product-moment correlation coefficients. For the $\mathrm{G} 2$ treatment, basal area reduction was set to $46 \%$ for correlation analysis with plot-averaged LAI and percent crown cover. A basal area reduction of $100 \%$ was used for correlation analysis with daily understory PPFD, since PPFD was measured only within the canopy gaps in these plots.

\section{Results}

The closed canopy of the unthinned, $\mathrm{CN}$ plots had an average LAI of $3.14,93.2 \%$ crown closure, and daily understory PPFD of about $7 \%$ of full sunlight (Table 1). The four thinning treatments created canopy openings of different number and size, reduced plot-averaged estimates of LAI and percent crown closure, and increased understory light levels (Table 1). The highest plot-averaged value of daily PPFD was $~ 18 \%$ in the $2 R$ treatment, but daily PPFD within canopy gaps of the G2 plots averaged $34 \%$. A significant correlation existed between thinning intensity and LAI $(r=-0.93, p \leq 0.008)$, percent crown closure $(r=-0.86, p \leq 0.03)$, and daily PPFD $(r=0.99$, $\mathrm{p} \leq 0.0001)$.

\section{Artificial regeneration}

Reduction in overstory basal area in the main study area had a significant, positive effect $(\mathrm{p} \leq 0.05)$ on seedling stem diameter, height, and volume, but not until the third growing season after thinning. Five years after planting, seedlings were generally larger in the $2 \mathrm{R}$ and $\mathrm{G} 1$ treatments and smaller in the $\mathrm{CN}$ and SLT treatments (Table 2). Thinning also had a strong effect on relative diameter $(p \leq 0.03)$, height $(p \leq 0.04)$, and volume $(p \leq 0.08)$ growth rates, with seedlings in the $2 R, 1 R$, and G1 treatments exhibiting a proportionally larger increase in size than those in the unthinned, $\mathrm{CN}$ plots (Table 2). By comparison, seedlings growing within canopy gaps in the G2 plots were much larger and exhibited higher relative growth rates.

Seedling stem size differed significantly $(\mathrm{p} \leq 0.05)$ among species in all five growing seasons. Initially, species variation in stem size was largely due to the smaller size of direct seeded red oak germinants relative to nursery stock. By year five, seedling diameter, height, and volume were generally larger for ash and pine than both types of oak seedlings (Table 2). Stem relative growth rates also differed among species in all five growing seasons ( $\mathrm{p} \leq 0.01)$, and tended to be lower in ash and oak planting stock than in pine and the direct seeded oak (Table 2). The general similarity in comparative growth response to thinning intensity among species is illustrated in Fig. 2.

Seedling survival ranged from 76 to $95 \%$ among thinning treatments in the first growing season after planting and declined slightly by year five (Table 3 ). Stem dieback followed by sprouting from the root collar occurred in $5.3 \%$ of the oak and $1.4 \%$ of the ash seedlings in the year of planting. Seedling survival was not influenced by thinning but differed $(\mathrm{p}<0.0001)$ 
Table 2. Mean ( \pm 1 SE) for several stem growth parameters for data pooled for thinning treatment (a) and species (b). Means followed by the same letter are not significantly different $(p \leq 0.05)$. The $G 2$ treatment was not included in ANOVA and mean comparison tests

\begin{tabular}{|c|c|c|c|c|c|c|}
\hline & \multicolumn{3}{|c|}{ Seedling stem size ( 5 yr) } & \multicolumn{3}{|c|}{ Stem relative growth rate } \\
\hline & Height (cm) & Diameter (mm) & Volume $\left(\mathrm{cm}^{3}\right)$ & Height $(5 \mathrm{yr})$ & Diameter (4 yr) & Volume (4 yr) \\
\hline \multicolumn{7}{|l|}{ a) Thinning } \\
\hline $\mathrm{CN}$ & $38.9(1.7)^{b}$ & $5.7(0.2)^{b}$ & $6.9(1.4)^{b}$ & $0.38(0.02)^{\mathrm{c}}$ & $0.12(0.01)^{\mathrm{c}}$ & $0.22(0.01)^{\mathrm{a}}$ \\
\hline IR & $54.8(1.6)^{\mathrm{ab}}$ & $7.5(0.2)^{\mathrm{b}}$ & $12.2(1.0)^{\mathrm{b}}$ & $0.55(0.02)^{\mathrm{ab}}$ & $0.28(0.01)^{\mathrm{ab}}$ & $0.38(0.01)^{\mathrm{a}}$ \\
\hline $2 \mathrm{R}$ & $72.3(2.4)^{\mathrm{a}}$ & $10.0(0.3)^{\mathrm{a}}$ & $32.0(3.1)^{\mathrm{a}}$ & $0.65(0.02)^{\mathrm{a}}$ & $0.40(0.02)^{\mathrm{a}}$ & $0.48(0.02)^{\mathrm{a}}$ \\
\hline SLT & $47.1(1.4)^{b}$ & $6.6(0.2)^{b}$ & $7.9(0.6)^{b}$ & $0.46(0.03)^{\mathrm{bc}}$ & $0.23(0.01)^{\mathrm{bc}}$ & $0.32(0.02)^{\mathrm{a}}$ \\
\hline G1 & $55.7(1.6)^{\mathrm{ab}}$ & $8.0(0.2)^{\mathrm{ab}}$ & $13.5(1.0)^{b}$ & $0.56(0.02)^{\mathrm{ab}}$ & $0.32(0.01)^{\mathrm{ab}}$ & $0.39(0.02)^{\mathrm{a}}$ \\
\hline G2 & $97.9(5.3)$ & $12.6(0.5)$ & $56.9(6.8)$ & $0.71(0.03)$ & $0.48(0.02)$ & $0.56(0.02)$ \\
\hline \multicolumn{7}{|l|}{ (b) Species } \\
\hline White ash & $57.0(1.8)^{\mathrm{a}}$ & $7.8(0.2)^{\mathrm{ab}}$ & $19.3(2.0)^{\mathrm{a}}$ & $0.31(0.02)^{c}$ & $0.23(0.01)^{b}$ & $0.27(0.02)^{b}$ \\
\hline White pine & $62.7(1.2)^{\mathrm{a}}$ & $8.7(0.2)^{\mathrm{a}}$ & $17.1(1.0)^{\mathrm{ab}}$ & $0.71(0.01)^{\mathrm{a}}$ & $0.32(0.01)^{\mathrm{a}}$ & $0.44(0.01)^{\mathrm{a}}$ \\
\hline Red oak $(\mathrm{p})^{*}$ & $45.8(1.4)^{b}$ & $6.9(0.1)^{\mathrm{b}}$ & $9.0(0.7)^{\mathrm{ab}}$ & $0.54(0.02)^{\mathrm{b}}$ & $0.25(0.01)^{\mathrm{ab}}$ & $0.36(0.02)^{\mathrm{ab}}$ \\
\hline Red oak (s)* & $38.9(2.1)^{\mathrm{b}}$ & $5.3(2.1)^{\mathrm{c}}$ & $5.2(0.8)^{\mathrm{b}}$ & $0.66(0.02)^{\mathrm{ab}}$ & $0.36(0.02)^{\mathrm{a}}$ & $0.45(0.02)^{\mathrm{a}}$ \\
\hline
\end{tabular}

*Planted (p) and seeded (s) red oak.

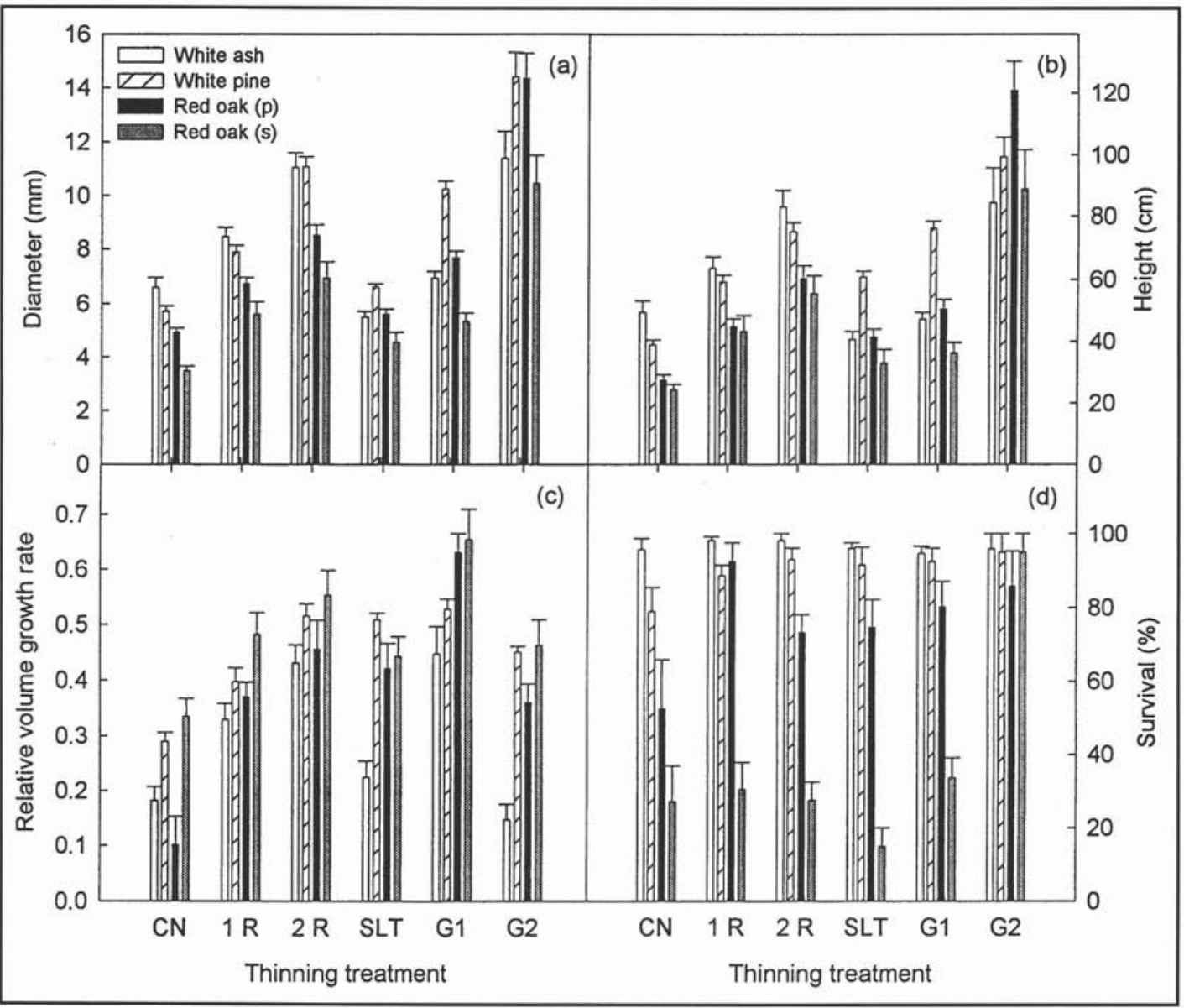

Fig. 2. Mean ( \pm 1 SE) diameter (a), height (b), relative stem volume growth rate (c), and percent survival (d) of underplanted tree seedlings five years after thinning. Red oak seedlings are separated into planted (p) and seeded (s) populations.

among species in years one and five and was ranked as follows: ash $=$ pine $>$ planted oak $\gg$ seeded oak (Table 2). Fifth year survival of ash was uniformly high $(>95 \%)$ for all treatments, while survival of pine and planted oak seedlings was enhanced by heavier thinning (Fig. 2). With the exception of the G2 treatment, only about $30 \%$ of the acorn planting spots produced at least one seedling the first growing season, as compared with about $90 \%$ survival for the planted oak (Fig. 2). Thereafter, survival of oak germinants was higher than that of planted oak.

Seedling growth response was also influenced by understory location relative to canopy gaps in the $\mathrm{G} 1$ and $\mathrm{G} 2$ treatments.
White pine seedlings planted in the northern-most row in each plot were exposed to relatively high light levels in the canopy opening of G1 plots, and were larger than ash and oak seedlings (Fig. 2,3). The size of pine seedlings declined to the east and west of plot centre as planting rows passed into the more shaded conditions of the selectively thinned portion of the plot (Fig. 3). By comparison, white ash seedlings planted in the third row were not exposed to the gap environment, and were similar in size to ash in the SLT treatment (Fig. 3). All three species exhibited best growth when planted beneath the canopy gaps in the $\mathrm{G} 2$ plots. 
Table 3. Results of a Tukey-Kramer multiple comparison test of mean differences in percent survival one and five years after planting. Means ( $\pm 1 \mathrm{SE}$ ) are presented for data pooled for (a) thinning and (b) species. Means lacking superscripts or sharing the same superscript are not significantly different $(p \leq 0.05)$. Data from the $\mathrm{G} 2$ thinning treatment were not included in ANOVA for thinning effects or in means by species

\begin{tabular}{lcc}
\hline & \multicolumn{2}{c}{ Survival (\%) } \\
\cline { 2 - 3 } & Year 1 & Year 5 \\
\hline (a) Thinning & $79.4(7.8)$ & $63.6(7.7)$ \\
CN & $82.3(7.5)$ & $77.5(7.4)$ \\
IR & $77.9(7.5)$ & $73.0(7.4)$ \\
2R & $76.3(9.2)$ & $69.2(8.6)$ \\
SLT & $82.7(7.5)$ & $75.2(6.7)$ \\
G1 & $95.4(2.1)$ & $92.9(3.0)$ \\
G2 & & \\
(b) Species & $99.4(0.4)^{\mathrm{a}}$ & $96.1(0.8)^{\mathrm{a}}$ \\
White ash & $100(0.0)^{\mathrm{a}}$ & $89.2(2.1)^{\mathrm{a}}$ \\
White pine & $90.2(2.0)^{\mathrm{b}}$ & $74.8(4.2)^{\mathrm{b}}$ \\
Red oak (p) & $29.2(3.7)^{\mathrm{c}}$ & $26.7(3.1)^{\mathrm{c}}$ \\
Red oak (s) & &
\end{tabular}

\section{Understory vegetation}

The understory vegetation survey identified 113 plant species in the young pine plantation (Table 4), but total percent cover was low (Appendix 1). More total species were present in the $\mathrm{CN}$ plots than any other thinning treatment, 22 of which only occurred in these undisturbed plots (Table 4). About $22 \%$ of the total species present in the study area were exotic, with the percentage of non-native species ranging from $24-32 \%$ among thinning treatments. By comparison, the understory vegetation in the older, previously disturbed plantation was more diverse and abundant, and included Heuchera americana $\mathrm{L}$. and Polytrichum formusum Hedw., species listed as very rare and uncommon to Ontario, respectively (Table 4, Appendix 1). Exotic species, predominantly herbaceous, were also common in the older plantation. Of the 167 plant species identified at both plantations, 26 were unique to the young plantation, while 56 occurred only in the older plantation.

Thinning had a significant effect $(\mathrm{p}<0.01)$ on plant diversity, with species richness increasing at higher thinning inten- sity (Fig. 4a). The response of species richness to thinning differed among functional plant groups (Fig. 4b). Richness of woody species was higher in the gap thinning treatments and herbaceous species exhibited a trend toward increased richness with heavier thinning. In contrast, species richness of cryptogams was reduced by thinning (Fig. 4b). The number of plot edges bordering other vegetation types had a positive, significant $(\mathrm{p}<0.001)$ effect on floral diversity. Species richness averaged $14 \pm 6,25 \pm 4$, and $48 \pm 7$ in plots with 0,1 , and $2-3$ exposed edges, respectively. Mean species richness of the older plantation was significantly higher than all but the $\mathrm{G} 2$ treatment of the younger plantation and also had a much higher richness of cryptogams (Fig. 4).

Natural regeneration of woody species was represented by 14 tree and 14 shrub species, but percent cover (total and for individual species) was uniformly low $(<1-2 \%)$ for all treatments (Appendix 1). The most common woody species were red pine and two exotic shrub species, Rhamnus cathartica $\mathrm{L}$. and Rubus idaeus $\mathrm{L}$. The ingress and development of natural regeneration of woody species has proceeded slowly, with lower abundance and richness observed in the larger size classes (Fig. 5). A slightly larger number of woody species was present in the older plantation, with richness and percent cover being much higher than the young plantation for all three height classes (Table 4, Fig. 5).

\section{Discussion}

Forest canopies have a substantial influence on the understory environment, buffering temperature changes, reducing light intensity, changing the spectral quality of solar radiation, and intercepting a significant proportion of precipitation (Anderson et al. 1969, Aussenac 2000). The growth and abundance of understory vegetation beneath intact forest canopies are strongly limited by heavy shade, reduced precipitation inputs, and root competition for moisture with overstory trees (Anderson $\mathrm{et} \mathrm{al}$. 1969, Canham et al. 1990, Bazzaz and Wayne 1994). Increased light, soil moisture, and nutrient availability and creation of microsites for colonization associated with canopy disturbance promote understory succession, dependent on the inten-

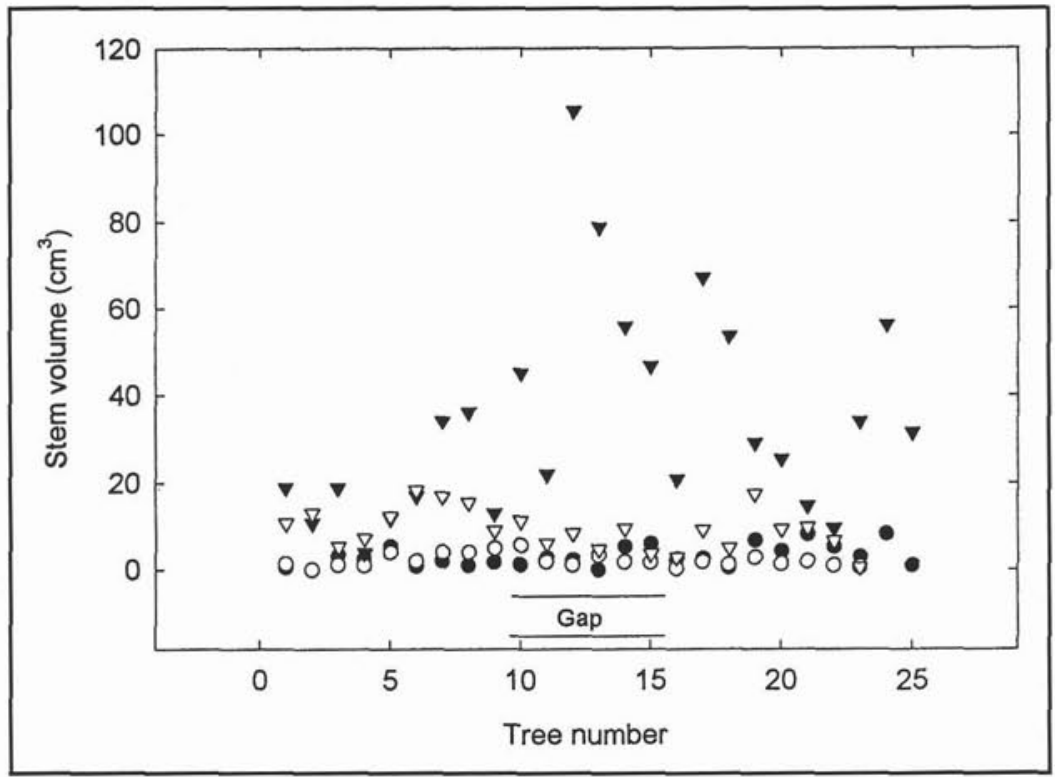

Fig. 3. Relationship of stem volume of white ash (circles) and white pine (triangles) seedlings with position along a planting row in plots thinned with the G1 (solid symbols) and SLT (open symbols) treatments. The approximate location and diameter of the canopy gap of the G1 plot relative to the planting row is noted. Planting rows were oriented in an eastwest direction. 
Table 4. Summary of the understory vegetation survey for the study area and neighbouring, older red pine plantation (CN2). The number of unique, exotic, and total species for three plant functional groups are presented by thinning treatment and plantation. Unique refers to species that only occur in plots of a given thinning treatment or a given plantation

\begin{tabular}{|c|c|c|c|c|c|c|c|c|c|}
\hline \multirow[b]{2}{*}{ Species group } & \multirow[b]{2}{*}{ Class } & \multicolumn{6}{|c|}{ Thinning treatment } & \multicolumn{2}{|c|}{ Plantation } \\
\hline & & $\mathrm{CN}$ & $1 R$ & SLT & $2 \mathbf{R}$ & G1 & G2 & Study area & $\mathrm{CN} 2$ \\
\hline \multirow[t]{3}{*}{ Woody } & Unique & 6 & 0 & 0 & 0 & 0 & 0 & 5 & 11 \\
\hline & Exotic & 3 & 3 & 3 & 2 & 3 & 3 & 3 & 3 \\
\hline & Total & 27 & 19 & 14 & 12 & 17 & 17 & 28 & 34 \\
\hline \multirow[t]{3}{*}{ Herbaceous } & Unique & 6 & 0 & 3 & 0 & 0 & 0 & 18 & 31 \\
\hline & Exotic & 22 & 15 & 14 & 11 & 19 & 19 & 25 & 24 \\
\hline & Total & 39 & 35 & 30 & 25 & 38 & 38 & 51 & 63 \\
\hline \multirow[t]{3}{*}{ Cryptogams } & Unique & 10 & 0 & 0 & 2 & 0 & 0 & 3 & 10 \\
\hline & Exotic & 0 & 0 & 0 & 0 & 0 & 0 & 0 & 0 \\
\hline & Total & 28 & 20 & 10 & 18 & 21 & 21 & 34 & 43 \\
\hline \multirow[t]{3}{*}{ All species } & Unique & 22 & 0 & 3 & 2 & 0 & 0 & 26 & 52 \\
\hline & Exotic & 25 & 18 & 17 & 13 & 22 & 22 & 28 & 27 \\
\hline & Total & 94 & 74 & 54 & 55 & 78 & 76 & 113 & 140 \\
\hline
\end{tabular}

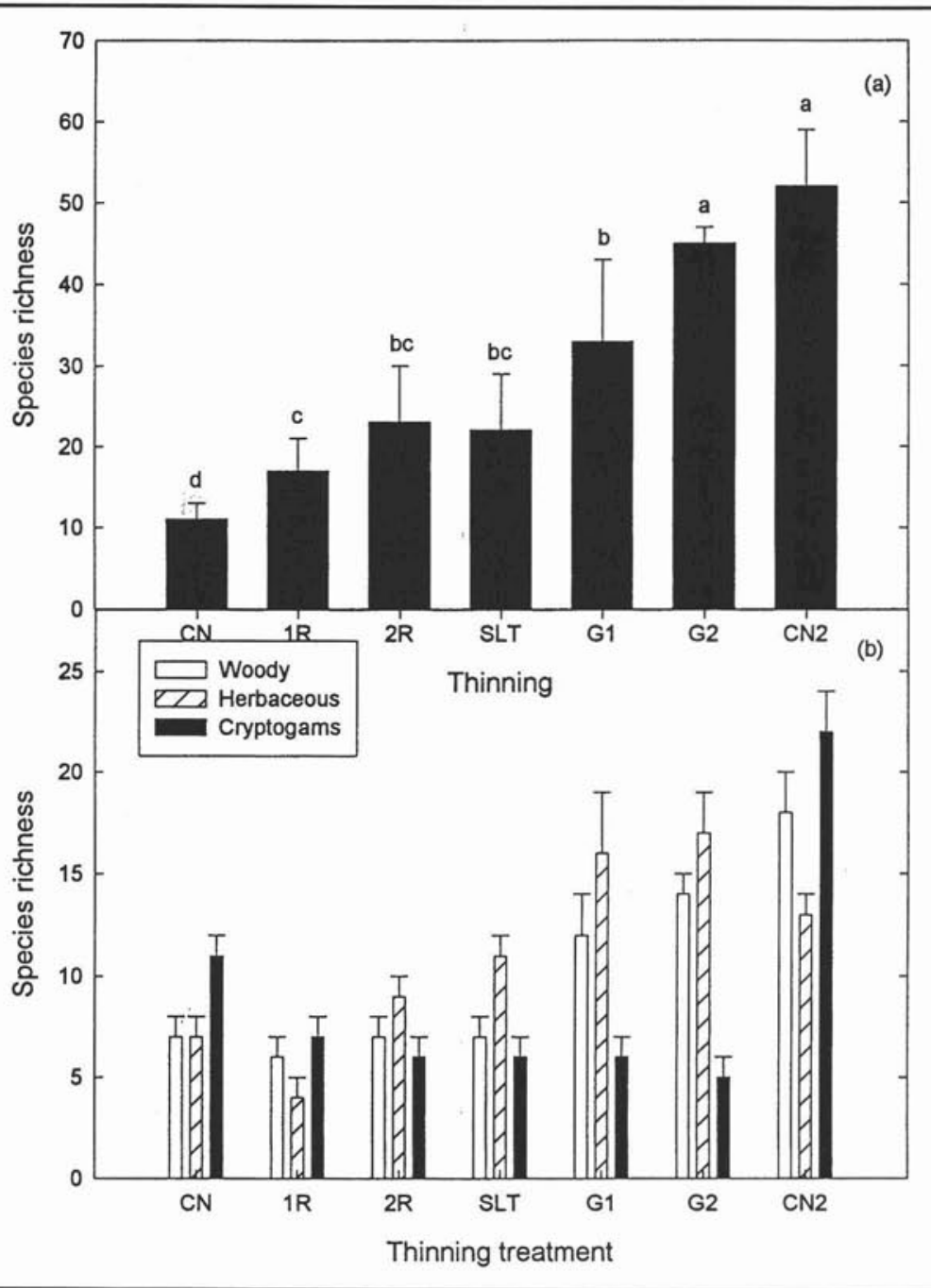

Fig. 4. Mean ( \pm 1 SE) species richness for understory vegetation (a) and plant functional groups (b) five years after thinning. The 70-year-old plantation is identified as $\mathrm{CN} 2$. Vertical bars in (a) sharing the same letter are not significantly different based on a Kruskal-Wallis test $(\mathrm{p}<0.05)$.

sity of disturbance (Connell 1989, Bazzaz and Wayne 1994, Coates and Burton 1997).

Thinning increased plot-averaged daily PPFD from $~ 7$ to $18 \%$ sunlight and improved the growth of underplanted seedlings, but understory light levels were much lower than the $40 \%$ sunlight needed for maximum shoot growth of the planted species (Sander 1990, Schlesinger 1990, Wendel and Smith 1990). Only within the canopy gaps of the G1 and G2 treatments where daily 


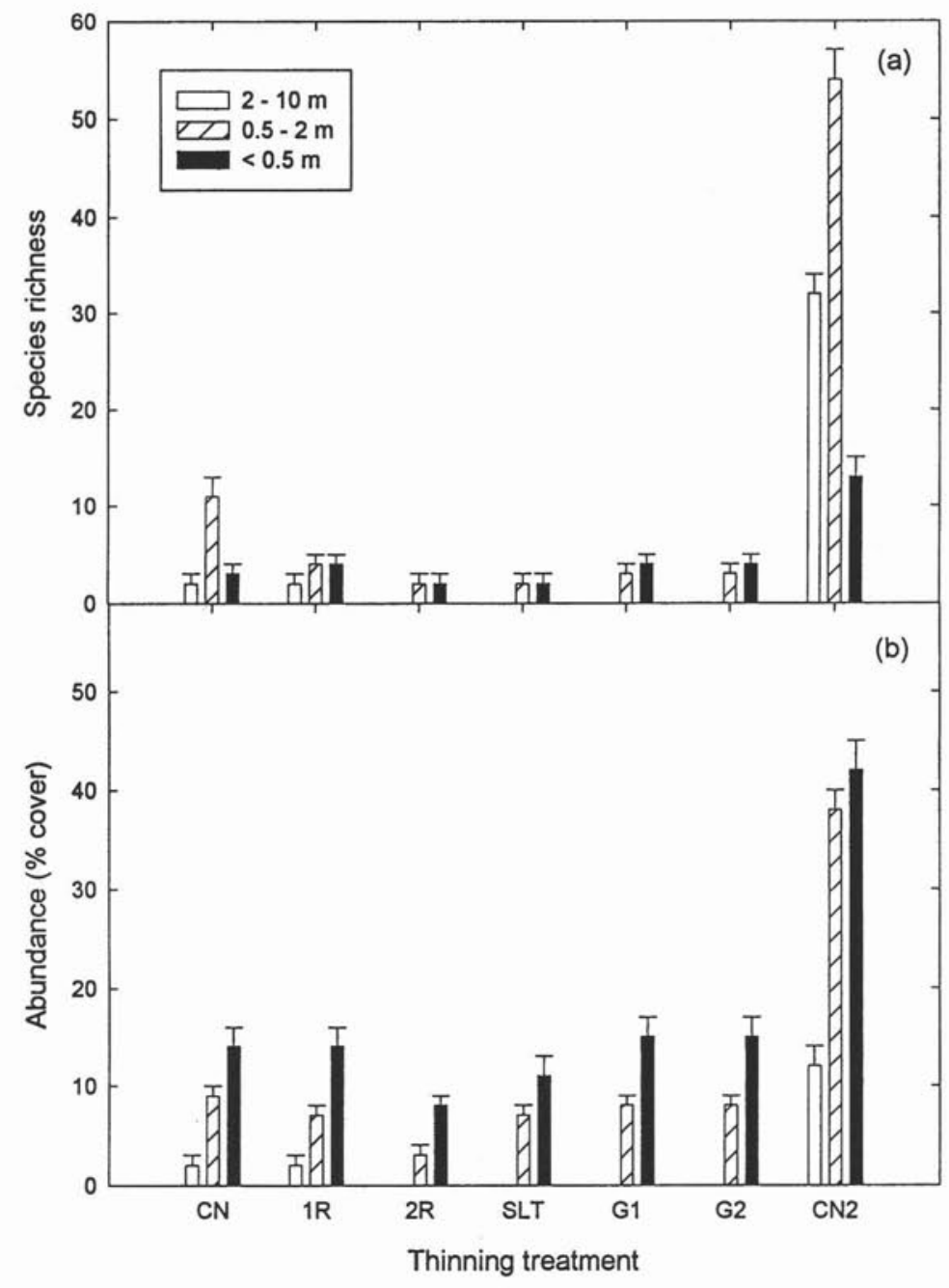

Fig. 5. Mean ( $\pm 1 \mathrm{SE})$ species richness (a) and abundance (b) for woody vegetation of three height classes. The 70-year-old plantation is identified as CN2.

PPFD was as high as $34 \%$, or perhaps in localized microsites of other treatments, did thinning result in light levels high enough to support vigorous shoot growth. For example, seedling diameter and height were about $50 \%$ larger and volume four times larger in the $2 \mathrm{R}$ than the SLT treatment despite comparable residual basal areas (Fig. 2). This is likely because light availability increased more in the larger canopy openings of the 2R treatment (Canham et al. 1990, Bazzaz and Wayne 1994), and in the area immediately surrounding the gap (i.e., the “extended gap") (Canham et al. 1990, Tryon et al. 1992).

Averaged over all thinning treatments, the growth potential of underplanted white pine was somewhat higher than for white ash and red oak seedlings. Although white ash seedlings can survive in heavily shaded forest understory, shoot growth is greatly reduced (Schlesinger 1990). Red oak seedlings growing in resource-limited environments have an inherently slow shoot growth habit associated with the preferential allocation of carbohydrate to root systems (Dey and Parker 1996). The higher relative shoot growth performance of pine was also related to more frequent shoot dieback in the two hardwood species. As many as $8 \%$ of the ash and oak seedlings exhibited partial stem dieback each year, but this occurred in $<2 \%$ of the pine.
Only slight growth differences were observed between direct seeded and planted oak. However, oak regeneration by seeding was substantially decreased by predation of acorns and young germinants. Partially consumed acorns and shell fragments were observed near many of the seeding spots at the end of the first growing season, suggesting small mammals were the primary source of this mortality. Better initial survival of seeded oak in the understory openings of the G2 plots is likely attributable to a more favourable environment for germination and early growth (Ashton and Larson 1996). Lack of protective overstory cover and higher exposure to predators in these openings may also have deterred herbivory (Webb and Willson 1985, Wright et al. 1998).

\section{Understory vegetation}

Thinning of conifer stands, including red pine, is often associated with increased diversity and abundance of understory flora (Dickmann et al. 1987, Bender et al. 1997, Thomas et al. 1999, Thysell and Carey 2000). In our study, understory species richness was positively related to thinning intensity and proximity to sources of seed, spores, etc., but frequency and abundance were low. Unfortunately, many of the 113 
species found in the understory were exotic $(25 \%)$ and/or invasive species common to the urban and agricultural landscapes of southern Ontario. These competitive species may displace or reduce populations of native species and significantly impede the conversion of conifer plantations to more natural forest conditions (Hobbs and Huenneke 1992, Bell and Newmaster 1998).

Thinning effects on understory species richness, percent cover, and frequency were attributable to harvesting disturbance of the forest floor, propagule availability, and, to a lesser extent, improved microenvironment for germination and establishment. Disturbance of the pine needle litter layer and exposure of mineral soil by logging activities was confined to small, localized areas. The availability of this substrate, the preferred seedbed of early and mid-successional tree species, was short-lived, being re-covered with litter within two or three years of thinning. The increased richness of woody and herbaceous species observed at higher thinning intensities was probably due in part to greater disturbance to the forest floor in the more heavily thinned plots. Localized increases in light, temperature, and precipitation beneath canopy openings may have encouraged germination and establishment on these substrates (Anderson et al. 1969, Peterson and Pickett 2000). Once established, however, the relatively low understory PPFD hindered the development of natural regeneration except in microsites located within small canopy openings.

The distance between the plantation and sources of propagules also limited colonization of the understory as indicated by the positive relationship between species richness and the number of edges of individual treatment plots. Migration of winddispersed tree species from neighbouring plant communities was probably confined to within $20-30 \mathrm{~m}$ of the parent tree (LePage et al. 2000). The relatively high frequency of Prunus, oak, Cornus, Rhamnus, and Rubus in the understory suggests that animals played an important role in the migration of woody species at our study site. Only natural regeneration of red pine was relatively abundant, due to seed from the overstory in large enough amounts to colonize mineral soil patches and to overcome the low receptivity of the litter layer (Ribbens et al. 1994, Reader et al. 1995).

Limited delivery of propagules, particularly by woodland herbs, to microsites of low receptivity greatly delayed understory colonization (i.e., low frequency and abundance) by desirable herbaceous species. Immigration of these species occurs infrequently due to their low reproductive output and poor adaptation for long-distance seed dispersal (Matlack 1994, Cain et al. 1998). Once established, these species exhibit gradual expansion and infill by clonal spread and seeds (Matlack 1994, Meier $\mathrm{et} \mathrm{al}$. 1995). These life history characteristics render these species susceptible to competition from exotic and ruderal species better adapted for aggressive colonization following disturbance.

Species richness of herbs, grasses, and sedges was higher at greater thinning intensities but lower diversity was evident in the older plantation. These species are favoured by the improved light and soil moisture conditions of canopy gaps, but they decrease in frequency with time after disturbance as woody species begin to dominate the understory (Anderson et al. 1969, Moore and Vankat 1986, Thomas et al. 1999). Conversely, cryptogam richness was higher in the sheltered understory microenvironments of the $\mathrm{CN}$ plots. Most of the plant species unique to this treatment were bryophytes. Many of these forest mesophytes are quite sensitive to drier, more exposed environments (Newmaster et al. 1998, Andersson and Hytteborn 1991), and decrease in abundance after relatively heavy thinning (Dickmann et al. 1987, Alaback and Hermann 1988). The older study plantation also had comparatively high cryptogam species richness, a common feature of later successional forest stands (Söderström 1988, Lesica et al. 1991, Newmaster et al. 1999). The greater microhabitat heterogeneity and moderate, humid understory microclimate of older stands are thought to favour the establishment of cryptogam species with slow growth, limited dispersal, and specialized substrate and microenvironmental needs (Pike et al. 1975, Rambo and Muir 1998).

\section{Conclusions and Management Recommendations}

Red pine plantations are well suited to even-aged, intensive forest management. Thinning of red pine plantations is commonly used to increase diameter and volume growth of selected crop trees, avoid mortality, and shorten the technical rotation (Lundgren 1981, Woods and Penner 2000). Future volume yields depend on the residual density, thinning method, thinning interval, and age at which the first thinning occurs (Lundgren 1981, Woods and Penner 2000). Many of these same factors have a strong influence on the diversity, abundance, and development of understory vegetation in red pine plantations (Rudolph et al. 1984, Dickmann et al. 1987, Bender et al. 1997). The results of our study suggest that "early" thinning of red pine plantations can help to produce high-value timber and enhance artificial and natural regeneration of native tree species.

Thinning red pine plantations to maintain a residual basal area of $25-30 \mathrm{~m}^{2} \mathrm{ha}^{-1}$ is recommended in Ontario and the Lake States for maximum volume production (Lundgren 1981, Rudolph et al. 1984, Smith and Woods 1997). However, where conversion is the primary objective and the merchantability of first removal is not a concern, thinning can be heavier and begin earlier, i.e., after crown closure. A residual basal area of 16-21 m² $\mathrm{ha}^{-1}$ may be a reasonable compromise between timber production and improved understory development (Dickmann et al. 1987, Bender et al. 1997). This objective can be achieved using a combination of underplanting and/or scarification, row removal, selection thinning, and canopy gap creation. Row removal is an appropriate method for initial thinning as it permits access for future thinning and accommodates selective removal of additional trees. Where windthrow is not a concern, double row removal and selection in the remaining three rows can be considered.

Alternatively, fourth row removal can be used in combination with selective thinning and canopy gap creation to promote succession and improve the quality of residual red pine. However, to reduce windthrow risk, no more than $25 \%$ of the remaining area should be placed in canopy gaps in the first thinning, and gaps should be linked to the cleared rows for access. Where possible, these openings should be located in areas where growth and condition of canopy trees is poor. Gap diameters of $50-100 \%$ of the height of the overstory are closer to the optimum size for canopy recruitment of mid-tolerant tree species (Hibbs 1982a,b; Coates 2000). Where gap thinning is preferred, desirable, mid-tolerant species mixtures can be planted with 1-2 m spacing, primarily within gaps for maximum growth. Natural regeneration can be encouraged by scarifying to expose mineral soil. Where nearby seed sources are limited, a combina- 
tion of scarifying and underplanting may be needed to promote the establishment of desirable species.

Further thinning should occur when stand density approaches the mortality initiation line of density management diagrams (about every 10 years) (Smith and Woods 1997). This thinning should improve spacing and quality of the residual trees, while creating additional, larger canopy gaps to promote natural regeneration. After two to three thinnings, or when red pine has reached rotation age, management efforts should focus on removing valuable, mature individuals and releasing advance reproduction.

Management of conifer plantations should be tailored to promote non-timber values as well, particularly in heavily developed, fragmented landscapes with few woodlands remaining. Early thinning to a lower residual density than recommended for maximum volume production will promote understory succession of woody and herbaceous plant species, increase the floral diversity of the plantation, and improve the visual appearance of these spatially symmetric monocultures (Dickmann et al. 1997). Special efforts should be made to limit the ingress and growth of exotic species. Subsequent thinning should not remove all the remaining canopy trees for timber. Retention of large red pine trees at variable spacing will increase the structural complexity of stands, promote biodiversity, improve wildlife habitat, and create a more aesthetically pleasing forest setting for recreational and educational use (Hansen et al. 1991, Bender et al. 1997, Hayes et al. 1997).

\section{Acknowledgements}

The able technical assistance of John Osmok, Greg Bales, Mike Allan, Brian Brown, Jeff Kokes, Marc Boudreau, Steve Watson, John Paterson, Denzil Irving, Jim Rice, Blake Laporte, Daryll Cairns, Gary Syroid, and Nick Hoffman is gratefully acknowledged. We also thank Frank Schnekenberger for his assistance with statistical analysis, and Lisa Buse, Cathy Nielsen, Silvia Strobl and two anonymous reviewers for their helpful comments on an earlier version of this manuscript. Finally, the support and cooperation of the Regional Municipality of Durham are greatly appreciated.

\section{References}

Alaback, P.B. and F.R. Herman. 1988. Long-term response of understory vegetation to stand density in Picea-Tsuga forests. Can. J. For. Res. 18: 1522-1530.

Anderson, R.C., O.L. Loucks and A.M. Swain. 1969. Herbaceous response to canopy cover, light intensity, and throughfall precipitation in coniferous forests. Ecology 50: 255-263.

Andersson, L.I. and H. Hytteborn. 1991. Bryophytes and decaying wood - a comparison between managed and natural forest. Holar. Ecol. 14: 121-130.

Ashton, M.S. and B.C. Larson. 1996. Germination and seedling growth of Quercus (section Erythrobalanus) across openings in a mixed-deciduous forest of southern New England, USA. For. Ecol. Manage. 80: 81-94.

Aussenac, G. 2000. Interactions between forest stands and microclimate: Ecophysiological aspects and consequences of silviculture. Ann. For. Sci. 57: 287-301.

Bazzaz, F.A. and P.W. Wayne. 1994. Coping with environmental heterogeneity: The physiological ecology of tree seedling regeneration across the gap-understory continuum. In M.M. Caldwell and R.W. Pearcy (eds.). Exploitation of Environmental Heterogeneity by Plants: Ecophysiological Processes Above- and Belowground. pp. 343-390. Academic Press, Inc., San Diego, CA.
Bell, F.W. and S.G Newmaster. 1998. Fallingsnow Ecosystem Project: Floral richness, abundance and diversity. In R.G. Wagner and D.G. Thompson (comps.). Third International Forest Vegetation Management Conference: Forest Vegetation Management and Ecosystem Sustainability—Popular Summaries. pp. 45-47, Ont. Min. Nat. Resour., Ont. For. Res. Inst., For. Res. Inf. Pap. No.141.

Sault Ste. Marie, ON.

Bender, L.C., D.L. Minnis and J.B. Haufer. 1997. Wildlife response to thinning red pine. N. J. Appl. For. 14: 141-146.

Borczon, E.L. 1986. Evergreen Challenge: The Agreement Forest Story. Ont. Min. Natur. Resour., Toronto, ON. 60 p.

Cain, M.L., H. Damman and A. Muir. 1998. Seed dispersal and the Holocene migration of woodland herbs. Ecol. Monogr. 68: 325-347. Canham, C.D., J.S. Denslow, W.J. Platt, J.R. Runkle, T.A. Spies and P.S. White. 1990. Light regimes beneath closed canopies and treefall gaps in temperate and tropical forests. Can. J. For. Res. 20: 620-631.

Coates, K.D. 2000. Conifer seedling response to northern temperate forest gaps. For. Ecol. Manage. 127: 249-269.

Coates, K.D. and P.J. Burton. 1997. A gap-based approach for development of silvicultural systems to address ecosystem management objectives. For. Ecol. Manage. 99: 337-354.

Connell, J.H. 1989. Some processes affecting the species composition in forest gaps. Ecology 70: 560-562.

Delcourt, H.R. and P.A. Delcourt. 2000. Eastern deciduous forests. In M.G. Barbour and W.D. Billings (eds.). North American Terrestrial Vegetation, Second Ed. pp. 358-395. Cambridge University Press, Edinburgh, UK.

Dey, D.C. and W.C. Parker. 1996. Regeneration of red oak (Quercus rubra L.) using shelterwood systems: ecophysiology, silviculture and management recommendations. Ont. Min. Nat. Resour., Ont. For. Res. Inst., Sault Ste. Marie, ON. For. Res. Inf. Pap. No. 126. $59 \mathrm{p}$.

Dickmann, D.I., W.J. O'Neill and N. Caveney. 1987. Wide-spaced red pine: a multiple use opportunity. N.J. Appl. For. 4: 44-45.

Fisher, R.A., A.S. Corbet and S.B. Williams. 1942. The relation between the number of species and the number of individuals in a random sample of an animal population. J. Anim. Ecol. 12: 42-58.

Hansen, A.J., T.A. Spies, F.J. Swanson and J.L. Ohmann. 1991. Conserving biodiversity in managed forests. Bioscience 41: 382-392. Hayes, J.P., S.S. Chan, W.H. Emmingham, J.C. Tappeiner, L.D. Kellogg and J.D. Bailey. 1997. Wildlife response to thinning young forests in the Pacific Northwest. J. For. 98: 28-33.

Hibbs, D.E. 1982a. Gap dynamics in a hemlock-hardwood forest. Can. J. For. Res. 12: 522-527.

Hibbs, D.E. 1982b. White pine in the transition hardwood forest. Can. J. Bot. 60: 2046-2053.

Hobbs, R.J. and L.F. Huenneke. 1992. Disturbance, diversity, and invasion: implications for conservation. Cons. Biol. 6: 324-337.

Horton, K.W. and G.H.D. Bedell. 1960. White and red pine. Ecology, silviculture and management. Can. Dept. North. Aff. Nat. Resour., Ottawa, ON. For. Br. Bull. 124. 185 p.

LePage, P.T., C.D. Canham, K.D. Coates and P. Bartemucci. 2000. Seed abundance versus substrate limitation of seedling recruitment in northern temperate forests of British Columbia. Can. J. For. Res. 30: 415-427.

Lesica, P., B. McCune, S.V. Cooper and W.S. Hong. 1991. Differences in lichen and bryophyte communities between old-growth and managed second-growth forests in the Swan Valley, Montana. Can. J. Bot. 69: 1745-1755.

Lundgren, A.L. 1981. The effect of initial number of trees per acre and thinning densities on timber yields from red pine plantations in the Lake State. USDA For. Serv. Res. Pap. NC-193. 25 p.

Matlack, G.R. 1994. Plant species migration in a mixed-history forest landscape in eastern North America. Ecology 75: 1491-1502. McIntosh, R.P. 1967. An index of diversity and the relation of certain concepts to diversity. Ecology 48: 392-404. 
Meier, A.J., S.P. Bratton and D.C. Duffy. 1995. Possible ecological mechanisms for loss of vernal-herb diversity in logged eastern deciduous forests. Ecol. Appl. 5: 935-946.

Messier, C. and P. Puttonen. 1995. Spatial and temporal variations in the light environment of developing Scots pine stands: the basis for a quick and efficient method of characterizing light. Can. J. For. Res. 25: 343-354.

Moore, M.R. and J.L. Vankat. 1986. Responses of the herb layer to the gap dynamics of a mature beech-maple forest. Am. Midl. Nat. 115: 336-347.

Mosquin, T., P.G. Whitney and D.E. McAlister. 1995. Canada's Biodiversity. Can. Mus. Nature, Ottawa, ON. 293 p.

Newmaster, S.G., A. Lehela, M.J. Oldham, P.W.C. Uhlig and S. McMurray. 1998. Ontario Plant List. Ont. Min. Nat.. Resour, Ont. For. Res. Inst., Sault Ste. Marie, ON. For. Res. Inf. Pap. No. 123. 650 p. Newmaster, S.G., F.W. Bell and D.W. Vitt. 1999. The effects of triclopyr and glyphosate on common bryophytes and lichens in northwestern Ontario. Can. J. For. Res. 29: 1101-1111.

Peet, K.P. 1974. The measurement of species diversity. Annu. Rev. Ecol. Syst. 5: 285-307.

Peterson, C.J. and S.T.A. Pickett. 2000. Patch type influences on regeneration in a western Pennsylvania, USA, catastrophic windthrow. Oikos 90: 489-500.

Pike, L.E., W.C. Denison, D.M. Tracey, M. A. Sherwood and F. M. Rhoades. 1975. Floristic survey of epiphytic lichens and bryophytes growing in old-growth conifers in western Oregon. The Bryologist 78: 1-39.

Rambo, T.R. and P.S. Muir. 1998. Forest floor bryophytes of Pseudotsuga menziesii-Tsuga heterophylla stands in Oregon: influences of substrate and overstory. The Bryologist 101: 116-130.

Reader, R.J., S.P. Bonser, T.E. Duralia and B.D. Bricker. 1995. Interspecific variation in tree seedling establishment in canopy gaps in relation to tree density. J. Veg. Sci. 6: 609-614.

Ribbens, E., J.A. Silander and S.W. Pacala. 1994. Seedling recruitment in forests: calibrating models to predict patterns of tree seedling dispersion. Ecology 75: 1794-1806.

Rowe, J.S. 1972. Forest regions of Canada. Can. For. Serv., Dept. Environ., Ottawa, ON. Publ. No. 1300. 172 p.

Rudolph, V.J., M.W. Day, W.A. Lemmien, J.N. Bright and J.J. Hacker. 1984. Thinning planted red pine in Michigan. Mich. St. Univ. Agric. Exp. Sta., Res. Rep. 461. 18 p.
Sander, I.L. 1990. Quercus rubra L. Northern Red Oak. In R.M. Burns and B.H. Honkala (tech. coords.). Silvics of North America. Vol. 2. Hardwoods. pp. 727-733. USDA Agric. Handbk. No. 654. Washington, DC.

SAS Institute Inc. 1989. SAS/STAT User's Guide, Version 6, Fourth Edition, Volume 1, Cary, NC. 943 p.

Schlesinger, R.C. 1990. Fraxinus americana L. White Ash, In R.M. Burns and B.H. Honkala (tech. coords.). Silvics of North America Vol. 2. Hardwoods. pp. 333-338. USDA Agric. Handbk. No. 654. Washington, DC.

Smith, D.J. and M.E. Woods. 1997. Red pine and white pine density management diagrams for Ontario. Ont. Min. Nat. Resour., Southcentral Sci. Sec., North Bay, ON. Tech. Rep. \#48. 31 p.

Söderström, L. 1988. The occurrence of epixylic bryophyte and lichen species in an old natural and a managed forest stand in northeast Sweden. Biol. Cons. 45: 169-178.

Thomas, S.C., C.B. Halpern, D.A. Falk, D.A. Ligouri and K.A. Austin. 1999. Plant diversity in managed forests: understory response to thinning and fertilization. Ecol. Appl. 9: 864-879.

Thysell, D.R. and A.B. Carey. 2000. Effects of forest management on understory and overstory vegetation: a retrospective study. USDA For. Serv. Gen. Tech. Rep., PNW-488. 41 p.

Tryon, E.H., M. Lanasa and E.C. Townsend. 1992. Radial growth response of understory sugar maple (Acer saccharum Marsh.) surrounding openings. For. Ecol. Manage. 55: 249-257.

Webb, S.L. and M.F. Willson. 1985. Spatial heterogeneity in postdispersal predation on Prunus and Uvularia seeds. Oecologia 67: 150-153. Wendel, G.W. and H.C. Smith. 1990. Pinus strobus L: Eastern White Pine. In R.M. Burns and B.H. Honkala (tech. coords.). Silvics of North America. Vol. 1. Conifers. pp. 476-488. USDA Agric. Handbk. No. 654. Washington DC.

Whitney, G.G. 1986. Relation of Michigan's presettlement pine forests to substrate and disturbance history. Ecology 67: 1548-1559. Woods, M.E. and M. Penner. 2000. Growth and yield response of red pine plantations to thinning. Ont. Min. Nat. Resour., Southcentral Sci. Sec., North Bay, ON. Tech. Note \#06. 36 p.

Wright, E.F., K.D. Coates and P. Bartemucci. 1998. Regeneration from seed of six tree species in the interior cedar-hemlock forests of British Columbia as affected by substrate and canopy gap position. Can. J. For. Res. 28: 1352-1364.

Appendix 1. Percent cover (\%), frequency of occurrence (F), and species rarity ranking (SR) of understory vegetation by thinning treatment. SR: S1, extremely rare; S2, very rare; S3, uncommon; S4, common; S5, very common; SE, exotic (Newmaster et al. 1998)

\begin{tabular}{|c|c|c|c|c|c|c|c|c|c|c|c|c|c|c|c|}
\hline \multirow[b]{3}{*}{ Species } & \multicolumn{15}{|c|}{ Thinning treatment } \\
\hline & \multicolumn{2}{|c|}{$\mathrm{CN}$} & \multicolumn{2}{|c|}{$1 \mathbf{R}$} & \multicolumn{2}{|c|}{ SLT } & \multicolumn{2}{|c|}{$2 \mathbf{R}$} & \multicolumn{2}{|c|}{ G1 } & \multicolumn{2}{|c|}{ G2 } & \multicolumn{2}{|c|}{ CN2 } & \multirow[b]{2}{*}{ SR } \\
\hline & $\%$ & $\mathbf{F}$ & $\%$ & $\mathbf{F}$ & $\%$ & $\mathbf{F}$ & $\%$ & $\mathbf{F}$ & $\%$ & $\mathbf{F}$ & $\%$ & $\mathbf{F}$ & $\%$ & $\mathbf{F}$ & \\
\hline \multicolumn{16}{|l|}{ Trees $>10 \mathrm{~m}$} \\
\hline Pinus resinosa & 75 & 1.00 & 65 & 1.00 & 65 & 1.00 & 75 & 1.00 & 65 & 1.00 & 60 & 1.00 & 75 & 1.00 & S5 \\
\hline Acer rubrum & & & & & & & & & & & & & 15 & 0.20 & S5 \\
\hline Pinus strobus & & & & & & & & & & & & & 10 & 0.20 & S5 \\
\hline \multicolumn{16}{|l|}{ Trees $<10 \mathrm{~m}$} \\
\hline Pinus resinosa & $<1$ & 1.00 & $<1$ & 1.00 & $<1$ & 1.00 & $<1$ & 1.00 & $<1$ & 1.00 & $<1$ & 1.00 & 2 & 1.00 & S5 \\
\hline Populus grandidentata & 2 & 0.25 & $<1$ & 0.25 & $<1$ & 0.13 & $<1$ & 0.13 & $<1$ & 0.31 & $<1$ & 1.00 & 4 & 0.19 & S5 \\
\hline Pinus strobus & $<1$ & 1.00 & $<1$ & 1.00 & $<1$ & 0.50 & $<1$ & 1.00 & $<1$ & 1.00 & $<1$ & 1.00 & 2 & 0.50 & S5 \\
\hline Quercus rubra & $<1$ & 1.00 & $<1$ & 1.00 & $<1$ & 1.00 & $<1$ & 0.50 & $<1$ & 1.00 & $<1$ & 1.00 & 2 & 0.75 & S5 \\
\hline Acer negundo & $<1$ & 0.50 & $<1$ & 0.06 & $<1$ & 0.06 & $<1$ & 0.06 & $<1$ & 0.13 & $<1$ & 0.13 & 1 & 0.25 & S5 \\
\hline Fraxinus americana & $<1$ & 0.50 & $<1$ & 1.00 & $<1$ & 0.50 & $<1$ & 1.00 & $<1$ & 0.94 & $<1$ & 1.00 & 2 & 0.25 & S5 \\
\hline Populus alba & $<1$ & 0.50 & $<1$ & 0.06 & $<1$ & 0.50 & $<1$ & 0.06 & $<1$ & 0.44 & & & $<1$ & 0.06 & SE \\
\hline Abies balsamea & $<1$ & 0.13 & & & & & & & & & & & 2 & 0.19 & S5 \\
\hline Acer rubrum & $<1$ & 0.13 & & & & & & & & & & & 2 & 0.50 & S5 \\
\hline Acer saccharum & $<1$ & 0.06 & $<1$ & 0.44 & $<1$ & 0.50 & $<1$ & 0.25 & $<1$ & 0.31 & $<1$ & 1.00 & 1 & 0.75 & S5 \\
\hline Fagus grandifolia & $<1$ & 0.06 & & & & & & & $<1$ & 0.50 & & & 2 & 0.50 & S5 \\
\hline Picea glauca & $<1$ & 0.06 & & & & & & & & & & & 2 & 0.13 & S5 \\
\hline Pinus banksiana & & & $<1$ & 0.38 & & & & & $<1$ & 0.19 & $<1$ & 1.00 & 2 & 0.50 & S5 \\
\hline Populus tremuloides & $<1$ & 0.06 & $<1$ & 0.44 & & & & & $<1$ & 0.44 & $<1$ & 1.00 & 2 & 0.25 & S5 \\
\hline Prunus serotina & $<1$ & 0.06 & $<1$ & 0.25 & & & 3 & 0.25 & $<1$ & 0.38 & & & 1 & 0.50 & S5 \\
\hline
\end{tabular}




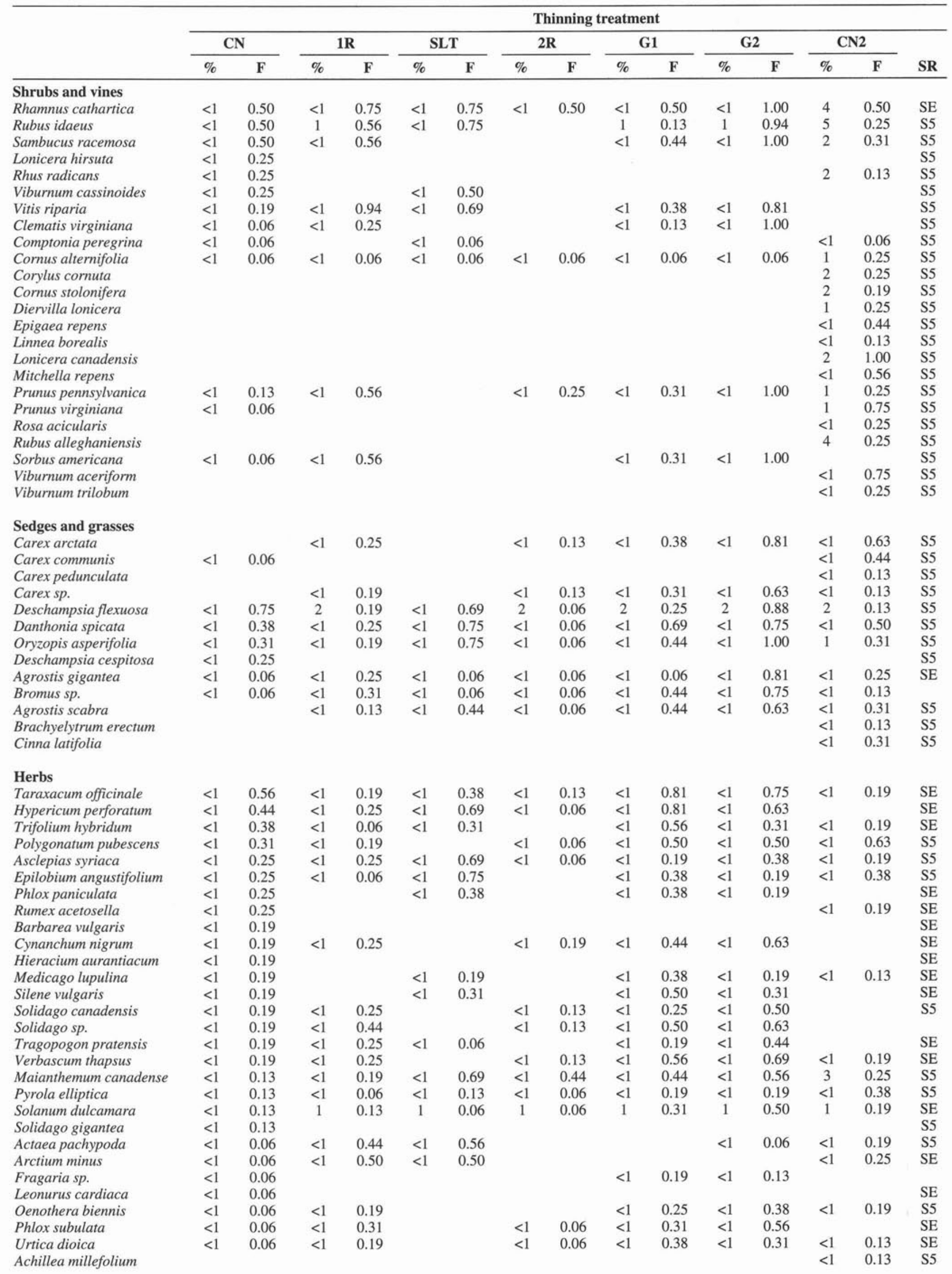




\begin{tabular}{|c|c|c|c|c|c|c|c|c|c|c|c|c|c|c|c|}
\hline & \multicolumn{15}{|c|}{ Thinning treatment } \\
\hline & \multicolumn{2}{|c|}{$\mathrm{CN}$} & \multicolumn{2}{|c|}{ 1R } & \multicolumn{2}{|c|}{ SLT } & \multicolumn{2}{|c|}{$2 \mathbf{R}$} & & & & & & & \\
\hline & $\%$ & $\mathbf{F}$ & $\%$ & $\mathbf{F}$ & $\%$ & $\mathbf{F}$ & $\%$ & $\mathbf{F}$ & $\%$ & $\mathbf{F}$ & $\%$ & $\mathbf{F}$ & $\%$ & $\mathbf{F}$ & SR \\
\hline Herbs (cont.) & & & & & & & & & & & & & & & \\
\hline Actaea rubra & & & & & & & & & & & & & $<1$ & 0.19 & S5 \\
\hline Amaranthus retroflexus & & & & & & & & & & & & & $<1$ & 0.25 & SE \\
\hline Anaphalus margaritacea & & & & & & & & & & & & & $<1$ & 0.19 & S5 \\
\hline Anemone virginiana & $<1$ & 0.06 & $<1$ & 0.25 & $<1$ & 0.25 & & & & & & & & & S5 \\
\hline Apocynum androsaemifolium & & & & & & & & & & & & & $<1$ & 0.13 & S5 \\
\hline Aquilegia canadensis & & & & & & & & & & & & & $<1$ & 0.19 & S5 \\
\hline Aralia nudicaulis & & & & & & & & & & & & & 1 & 0.19 & S5 \\
\hline Artemesia biennis & & & & & & & & & & & & & $<1$ & 0.19 & SE \\
\hline Capsella bursa-pastoris & & & & & & & & & & & & & $<1$ & 0.19 & SE \\
\hline Centaurea maculosa & & & & & & & & & & & & & $<1$ & 0.19 & SE \\
\hline Chenopodium album & & & & & & & & & & & & & $<1$ & 0.25 & SE \\
\hline Cirsium arvense & $<1$ & 0.06 & $<1$ & 0.19 & $<1$ & 0.44 & & & $<1$ & 0.19 & $<1$ & 0.75 & $<1$ & 0.25 & SE \\
\hline Cirsium sp. & & & $<1$ & 0.25 & $<1$ & 0.44 & & & & & & & $<1$ & 0.06 & \\
\hline Clintonia borealis & & & & & & & & & & & & & $<1$ & 0.13 & S5 \\
\hline Conyza canadensis & & & & & & & & & & & & & $<1$ & 0.19 & S5 \\
\hline Cornus canadensis & & & & & & & & & & & & & $<1$ & 0.25 & S5 \\
\hline Daucus carota & $<1$ & 0.06 & $<1$ & 0.38 & & & $<1$ & 0.06 & $<1$ & 0.38 & $<1$ & 0.38 & & & SE \\
\hline Echium vulgare & & & & & & & & & $<1$ & 0.19 & $<1$ & 0.13 & & & SE \\
\hline Erigeron philadelphicus & & & & & & & & & & & & & $<1$ & 0.19 & S5 \\
\hline Fragaria vesca & & & & & & & & & & & & & $<1$ & 0.19 & S5 \\
\hline Fragaria virginiana & & & & & $<1$ & 0.50 & & & & & & & $<1$ & 0.38 & SE \\
\hline Galium triflorum & & & & & $<1$ & 0.38 & & & & & & & $<1$ & 0.25 & S5 \\
\hline Geranium bicknelli & & & & & & & & & & & & & $<1$ & 0.19 & S4 \\
\hline Heuchera americana & & & & & & & & & & & & & $<1$ & 0.19 & S2 \\
\hline Hieracium praealtum & $<1$ & 0.06 & $<1$ & 0.56 & $<1$ & 0.25 & $<1$ & 0.25 & $<1$ & 0.19 & $<1$ & 0.19 & $<1$ & 0.13 & SE \\
\hline Matricaria matricarioides & & & & & & & & & & & & & $<1$ & 0.19 & SE \\
\hline Medicago sativa & & & & & & & & & & & & & $<1$ & 0.25 & SE \\
\hline Melilotus alba & & & & & & & & & & & & & $<1$ & 0.25 & SE \\
\hline Plantago major & & & & & & & & & $<1$ & 0.19 & $<1$ & 0.19 & $<1$ & 0.13 & SE \\
\hline Potentilla recta & & & $<1$ & 0.13 & $<1$ & 0.19 & & & $<1$ & 0.38 & $<1$ & 0.31 & $<1$ & 0.19 & S5 \\
\hline Rudbeckia hirta & & & $<1$ & 0.25 & $<1$ & 0.44 & $<1$ & 0.13 & $<1$ & 0.19 & $<1$ & 0.50 & & & S5 \\
\hline Sanicula marilandica & & & & & & & & & & & & & $<1$ & 0.19 & S5 \\
\hline Sonchus arvensis & & & & & & & & & & & & & $<1$ & 0.19 & SE \\
\hline Stellaria media & & & & & & & & & & & & & $<1$ & 0.19 & SE \\
\hline Streptopus roseus & & & & & & & & & & & & & $<1$ & 0.50 & S5 \\
\hline Tragopogon porrifolius & & & & & & & & & & & & & $<1$ & 0.19 & SE \\
\hline Trientalis borealis & & & & & & & & & & & & & 2 & 0.63 & S5 \\
\hline Veronica officinalis & & & $<1$ & 0.06 & $<1$ & 0.44 & $<1$ & 0.06 & $<1$ & 0.13 & $<1$ & 0.38 & $<1$ & 0.25 & SE \\
\hline Viola sp. & & & & & $<1$ & 0.50 & & & & & & & & & \\
\hline Waldsteinia fragarioides & & & & & & & & & & & & & $<1$ & 0.06 & S5 \\
\hline Pteridophytes & & & & & & & & & & & & & & & \\
\hline Equisetum hyemale & $<1$ & 0.25 & $<1$ & 0.19 & $<1$ & 0.50 & $<1$ & 0.19 & $<1$ & 0.50 & $<1$ & 0.63 & $<1$ & 0.25 & S5 \\
\hline Equisetum sylvaticum & $<1$ & 0.25 & $<1$ & 0.13 & & & $<1$ & 0.19 & $<1$ & 0.38 & $<1$ & 0.56 & $<1$ & 0.13 & S5 \\
\hline Athyrium filix-femina & $<1$ & 0.13 & $<1$ & 0.31 & & & $<1$ & 0.19 & $<1$ & 0.44 & $<1$ & 0.63 & $<1$ & 0.13 & S5 \\
\hline Dryopteris carthusiana & $<1$ & 0.13 & $<1$ & 0.25 & & & $<1$ & 0.13 & $<1$ & 0.25 & $<1$ & 0.50 & 1 & 0.63 & S5 \\
\hline Dryopteris intermedia & & & & & & & & & & & & & $<1$ & 0.81 & S5 \\
\hline Dryopteris marginalis & & & & & & & & & & & & & $<1$ & 0.63 & S5 \\
\hline Onoclea sensibilis & & & $<1$ & 0.31 & & & $<1$ & 0.19 & $<1$ & 0.31 & $<1$ & 0.44 & & & S5 \\
\hline Pteridium aquilinum & $<1$ & 0.13 & $<1$ & 0.19 & & & $<1$ & 0.19 & $<1$ & 0.25 & $<1$ & 0.81 & 2 & 0.13 & S5 \\
\hline Bryophytes & & & & & & & & & & & & & & & \\
\hline Brachythecium salebrosum & $<1$ & 0.94 & $<1$ & 0.31 & $<1$ & 0.50 & $<1$ & 0.25 & $<1$ & 1.00 & $<1$ & 1.00 & $<1$ & 0.75 & S5 \\
\hline Polytrichum commune & $<1$ & 0.50 & $<1$ & 0.31 & & & & & $<1$ & 0.75 & $<1$ & 0.63 & $<1$ & 0.50 & S5 \\
\hline Ceratodon purpureus & $<1$ & 0.38 & $<1$ & 0.19 & $<1$ & 0.50 & $<1$ & 0.06 & $<1$ & 0.63 & $<1$ & 0.81 & & & S5 \\
\hline Pleurozium schreberi & $<1$ & 0.38 & $<1$ & 0.25 & $<1$ & 0.50 & $<1$ & 0.06 & $<1$ & 0.63 & $<1$ & 0.69 & 2 & 0.19 & S5 \\
\hline Pohlia nutans & $<1$ & 0.25 & & & & & & & $<1$ & 0.31 & $<1$ & 0.25 & $<1$ & 0.63 & S5 \\
\hline Plagiothecium laetum & $<1$ & 0.19 & & & & & & & & & & & $<1$ & 0.19 & S5 \\
\hline Polytrichum juniperinum & $<1$ & 0.19 & $<1$ & 0.13 & & & & & $<1$ & 0.56 & $<1$ & 0.63 & $<1$ & 0.50 & S5 \\
\hline Brachythecium oedipodium & $<1$ & 0.06 & $<1$ & 0.38 & & & $<1$ & 0.38 & $<1$ & 0.81 & $<1$ & 0.94 & $<1$ & 0.56 & S5 \\
\hline Brachythecium reflexum & $<1$ & 0.06 & & & & & & & & & & & $<1$ & 0.56 & S4 \\
\hline Callicladium haldanianum & $<1$ & 0.06 & $<1$ & 0.19 & & & & & $<1$ & 0.81 & $<1$ & 0.63 & $<1$ & 0.69 & S5 \\
\hline Climacium dendroides & $<1$ & 0.06 & & & & & & & & & & & $<1$ & 0.19 & S5 \\
\hline Dicranum flagellare & $<1$ & 0.06 & & & & & & & & & & & $<1$ & 0.56 & S5 \\
\hline Dicranum fuscescens & $<1$ & 0.06 & & & & & & & & & & & $<1$ & 0.31 & S5 \\
\hline Dicranum montanum & $<1$ & 0.06 & & & & & & & & & & & $<1$ & 0.69 & S5 \\
\hline Dicranum polysetum & $<1$ & 0.06 & & & $<1$ & 0.50 & & & & & & & 4 & 0.13 & S5 \\
\hline Dicranum scoparium & $<1$ & 0.06 & & & & & $<1$ & 0.44 & & & & & $<1$ & 0.19 & S5 \\
\hline Euryhchium pulchellum & $<1$ & 0.06 & & & & & & & & & & & $<1$ & 0.31 & S5 \\
\hline Hedwigia ciliata & & & & & & & $<1$ & 0.06 & & & & & & & S5 \\
\hline
\end{tabular}




\begin{tabular}{|c|c|c|c|c|c|c|c|c|c|c|c|c|c|c|c|}
\hline & \multicolumn{15}{|c|}{ Thinning treatment } \\
\hline & \multicolumn{2}{|c|}{$\mathrm{CN}$} & \multicolumn{2}{|c|}{ 1R } & \multicolumn{2}{|c|}{ SLT } & \multicolumn{2}{|c|}{$2 \mathbf{R}$} & \multicolumn{2}{|c|}{ G1 } & \multicolumn{2}{|c|}{ G2 } & \multicolumn{2}{|c|}{ CN2 } & \multirow[b]{2}{*}{ SR } \\
\hline & $\%$ & $\mathbf{F}$ & $\%$ & $\mathbf{F}$ & $\%$ & $\mathbf{F}$ & $\%$ & $\mathbf{F}$ & $\%$ & $\mathbf{F}$ & $\%$ & $\mathbf{F}$ & $\%$ & $\mathbf{F}$ & \\
\hline \multicolumn{16}{|l|}{ Bryophytes (cont.) } \\
\hline Hyclomium splendens & $<1$ & 0.06 & & & & & & & & & & & $<1$ & 0.06 & S5 \\
\hline Hypnum pallescens & & & & & & & $<1$ & 0.31 & & & & & $<1$ & 0.31 & S4 \\
\hline Leucobryum glaucum & & & & & & & & & & & & & $<1$ & 0.13 & S5 \\
\hline Mnium spinulosum & & & & & & & & & & & & & $<1$ & 0.63 & S5 \\
\hline Plagiomnium medium & $<1$ & 0.06 & & & & & & & & & & & $<1$ & 0.19 & S5 \\
\hline Polytrichum formosum & & & & & & & & & & & & & $<1$ & 0.13 & S3 \\
\hline Ptilidium ciliare & & & & & & & & & & & & & $<1$ & 0.13 & S5 \\
\hline Ptilium crista-castrensis & & & & & & & & & & & & & $<1$ & 0.50 & S5 \\
\hline Ptilidium pulcherrimum & & & $<1$ & 0.19 & $<1$ & 0.06 & & & $<1$ & 0.56 & $<1$ & 0.56 & $<1$ & 0.94 & S5 \\
\hline Rhytidiadelphus triquetrus & & & $<1$ & 0.19 & $<1$ & 0.31 & $<1$ & 0.06 & $<1$ & 0.50 & $<1$ & 0.56 & $<1$ & 0.25 & S5 \\
\hline Sanionia uncinata & & & $<1$ & 0.06 & $<1$ & 0.50 & & & $<1$ & 0.63 & $<1$ & 0.63 & $<1$ & 0.69 & S5 \\
\hline Tetraphis pellucida & & & $<1$ & 0.19 & $<1$ & 0.06 & $<1$ & 0.06 & $<1$ & 0.38 & $<1$ & 0.63 & $<1$ & 0.50 & S5 \\
\hline Thuidium delicatulum & & & $<1$ & 0.19 & $<1$ & 0.06 & $<1$ & 0.06 & $<1$ & 0.50 & $<1$ & 0.88 & $<1$ & 0.13 & S5 \\
\hline \multicolumn{16}{|l|}{ Lichens } \\
\hline Cladonia coniocraea & $<1$ & 0.06 & $<1$ & 0.13 & & & $<1$ & 0.13 & $<1$ & 0.50 & $<1$ & 0.75 & $<1$ & 0.81 & S5 \\
\hline Cladonia cristatella & $<1$ & 0.06 & & & & & & & & & & & $<1$ & 0.31 & S5 \\
\hline Peltigera canina & $<1$ & 0.06 & & & & & & & & & & & $<1$ & 0.19 & S5 \\
\hline Hypogymnia physodes & & & & & & & & & & & & & $<1$ & 0.13 & S5 \\
\hline Parmelia sulcata & & & & & & & & & & & & & $<1$ & 0.13 & S5 \\
\hline Icmadophila sp. & & & & & & & & & & & & & $<1$ & 0.06 & S4 \\
\hline
\end{tabular}

